\title{
An Apparatus for Facilitating the Manual Tabulation of Phytosociological Data
}

\author{
by \\ P. J. Müller,* M. J. A. Werger,* B. J. Coetzee,* D. Edwards* and \\ N. G. Jarman*
}

\begin{abstract}
Attempts by various continental workers to mechanize and facilitate compilation of BraunBlanquet phytosociological tables from raw data are shortly reviewed and a new apparatus for this purpose is described. The apparatus consists of a table with aluminium channels in which different headed rivets can be placed, symbolizing cover-abundance values. With this apparatus phytosociological tables can be compiled in two stages.
\end{abstract}

In phytosociological techniques, especially those developed by the ZürichMontpellier School, the manual ordering of stands and species for preparing the synthesis tables by rewriting has always been a time consuming procedure and a potential source of errors.

The usual method of table preparation in the Zürich-Montpellier School was described in detail by Ellenberg (1956). Shortened English and French translations of the procedure were given by Küchler (1967) and Gounot (1969), respectively.

Attempts to simplify and mechanize the tabulation procedure have been made by several workers. Wilmanns (1959) described a method using small wooden blocks with holes bored through them. Cover-abundance figures were written on each block and the sequence of stands or species was changed by putting a rod through the holes and moving the entire row or column. The method appears to be useful only with small numbers of stands and species, up to about 60 of each. Another disadvantage is that during tabulation the set must be handled very carefully, because one block out of place could easily result in disarrangement of the table structure. This is particularly so when several rows or columns are simultaneously removed from their positions and movability of all those remaining has to be retained. Similar considerations also apply to Margl's (1967) table.

Ellenberg \& Christofolini (1964) suggested the use of visual 'punch cards'. The species present in each relevé were punched on one card. Cover-abundance values were marked by symbols around each hole. On a light-table the cards were then compared one by one with a 'standard' card on presence alone. The 'standard' card can be chosen at random. Ellenberg (1968) described a modification of this technique, where cover-abundance values for each of the species were punched as logical sums. These techniques proved to be useful where the vegetation has already been largely classified and the vegetation units described, and where only additional relevés needed to be arranged and included in the existing data material. They may, however, not be readily applicable to data of virtually unknown areas.

Sophisticated techniques for tabulation by computer were recently developed by Stockinger \& Holzner (1970) and by Spatz \& Siegmund (1971). These methods seem to be particularly useful for the objective and rapid processing of a vast amount of stand and species data. When the amount of data is not too large, and the time spent in preparing the data and the cost of operating the computer are important considerations, the apparatus presented here should prove useful.

* Botanical Research Institute, Department of Agricultural Technical Services, P.O. Box 994, Pretoria 
We developed an apparatus which can be used to rearrange and order a matrix without the need to rewrite the various stages described by Ellenberg (1956) in the normal tabulation method. In the present case the apparatus was designed to handle a matrix of up to $124 \times 130$.

As columns or rows in the usual table matrix, we used aluminium channel, $8 \mathrm{~mm}$ wide, $5 \mathrm{~mm}$ high and $100 \mathrm{~cm}$ long, in which every $8 \mathrm{~mm}$ a $3 \mathrm{~mm}$ diameter hole, was drilled, thus resulting in 124 holes per channel. Rivets, $3 \mathrm{~mm}$ in diameter, $\pm 12 \mathrm{~mm}$ long, with cheese-heads of $7 \mathrm{~mm}$ diameter, fitted into the holes. The heads of the rivets were sprayed in different colours, symbolizing different cover-abundance values. The advantage of using aluminium channels with rivets in lieu of blocks is that, if one rivet is accidently removed, then the rest of the arrangement cannot be affected as a result.

The channels fitted into the raised edges of a table measuring $100 \mathrm{~cm}$ wide and $120 \mathrm{~cm}$ long. At one end the channels fit under a flat aluminium bar fixed to that edge of the table, and at the other end they can be fitted under a moveable flat aluminium bar, thus providing extra stability when an arrangement of the channels has been completed or is interrupted. To enable the channels to slide smoothly, they are supported by five metal edges let into the table surface.

For tabulation of the data two such tables should be available. From the field data the raw phytosociological table is set up on the first table, using a channel for either a species or a stand, and the different coloured rivets for cover-abundance values. The channels are then arranged in the desired sequence. The second table is placed so that the direction of the channels is perpendicular to that of the one in the first table, and the pattern of the first table is copied on to the second table. If in the first table the species (rows) were arranged, stands (columns) can now be shifted on the second table or vice versa. In this way the complete phytosociological table can be quickly arranged in two stages, without rewriting being necessary, thus avoiding an important potential source of errors. The end result can be copied in writing from the second table. The apparatus can also be used for processing other data as the sprayed rivets can be used to represent symbols for life forms, habitat features, and other meaningful ecological variables.

We wish to acknowledge the technical assistance of Mr. N. L. Galpin.

\section{Samevatting}

Pogings deur verskillende kontinentale werkers om die samestelling van BraunBlanquet-plantsosiologiese tabelle uit veldgegewens, te meganiseer en te vergemaklik, word kortliks bespreek. 'n Nuwe apparaat vir hierdie doel word beskryf. Dit bestaan uit ' $n$ tafel met aluminiumgeute, waarin klinknaels geplaas kan word, met verskillend gekleurde koppe, wat verskillende bedekking-abundansiewaardes voorstel. Met hierdie apparaat kan plantsosiologiese tabelle in twee stappe saamgestel word.

\section{REFERENCES}

Ellengerg, H., 1956. Aufgaben und Methoden der Vegetationskunde. Phytologie IV, I, ed. H. Walter Stuttgart: Ulmer.

EllenberG, H., 1968. Sichtlochkarten zur Ordnung, Klassifikation und Analyse pflanzensoziologischer Waldaufnahmen. in: Pflanzensoziologische Systematik, Int. Symp. Stolzenau, 1964, ed. R. Tüxen. Den Haag: Junk.

EllenberG, H. \& ChristofolinI, G., 1964. Sichtlochkarten als Hilfsmittel zur Ordnung und Auswertung von Vegetationsaufnahmen. Ber. Geobot. Inst. ETH, Stift. Rüibel, 35: 124-134.

Gounot, M., 1969. Méthodes d'étude quantitative de la végétation. Paris: Masson.

KüCHLER, A. W., 1967. Vegetation mapping. New York: Ronald Press.

MARGL, H., 1967. Ein Gerät zum raschen Ordnen einer Tabelle. Forstl. BVA Wien. Informationsdienst 109.

Spatz, G. \& Siegmund, J., 1971. Eine Methode zur tabellarischen Ordination, Klassifikation und ökologischen Auswertung pflanzensoziologischen Bestandsaufnahmen durch den Computer. Vegetatio: in the press.

Stockinger, F. J. \& HolzNer, W. F., 1970. Rationelle Methode zur Auswertung pflanzensoziologischer Aufnahmen mittels Elektronenrechner. 14th Int. Sym. Rinteln: in the press.

WilmanNs, O., 1959. Ein Gerät zur Mechanisierung von Tabellenarbeit. Ber. disch. bot. Ges. 72 : 419-420. 

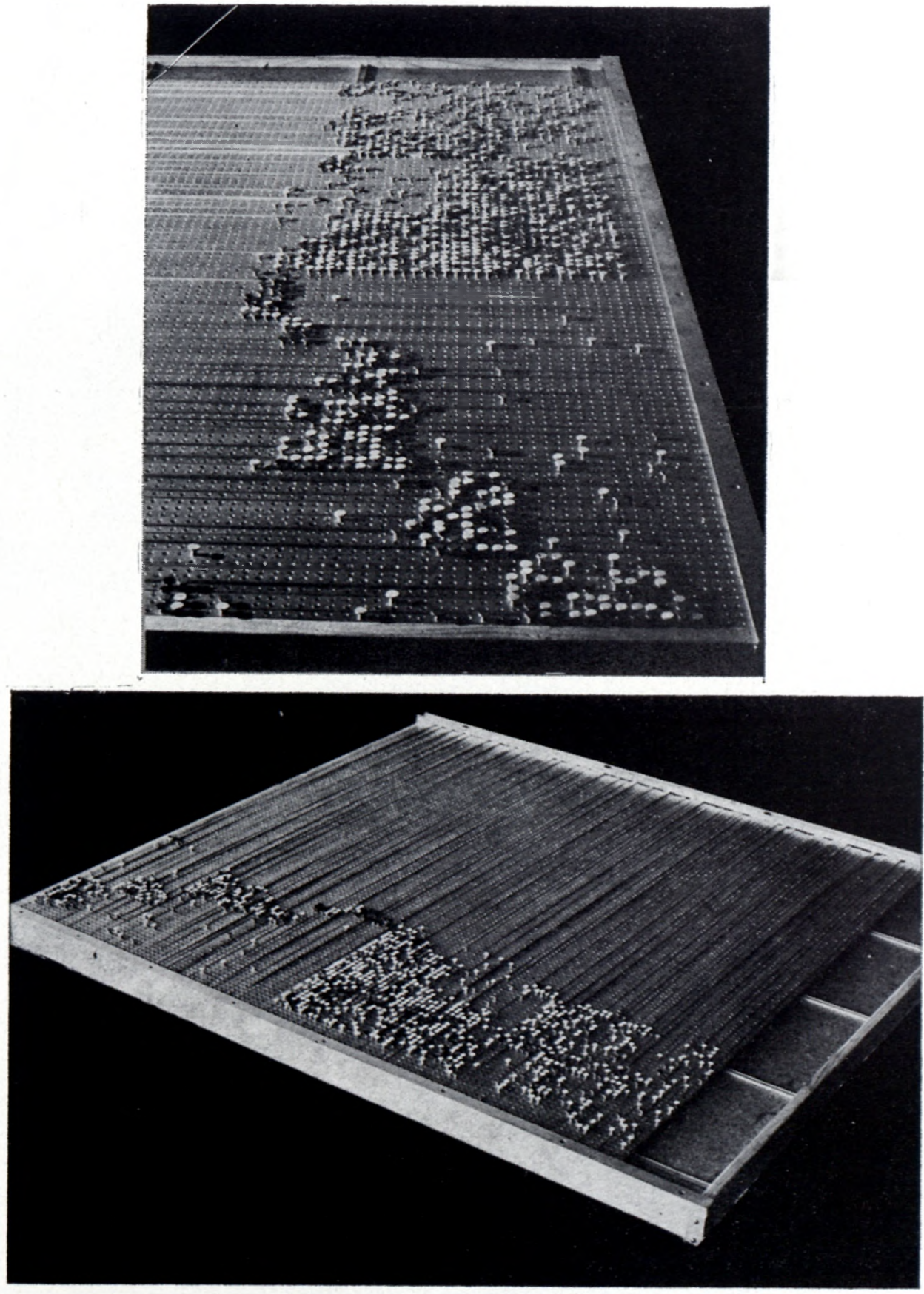

Plate 1.-Two views of the apparatus designed for facilitating the manual tabulation of phytosociological data. 
